Relations industrielles

Industrial Relations

\title{
Labor Relations and Productivity in the Building Trades. By W. Haber and H.M. Levinson. Ann Arbor: Bureau of Industrial Relations, University of Michigan, 1956. 266 pp. \$4.75.
}

\section{Louis-Marie Tremblay}

Volume 13, numéro 2, avril 1958

URI : https://id.erudit.org/iderudit/1022457ar

DOI : https://doi.org/10.7202/1022457ar

Aller au sommaire du numéro

\section{Éditeur(s)}

Département des relations industrielles de l’Université Laval

ISSN

0034-379X (imprimé)

1703-8138 (numérique)

Découvrir la revue

Citer ce compte rendu

Tremblay, L.-M. (1958). Compte rendu de [Labor Relations and Productivity in the Building Trades. By W. Haber and H.M. Levinson. Ann Arbor: Bureau of Industrial Relations, University of Michigan, 1956. 266 pp. \$4.75.] Relations industrielles / Industrial Relations, 13(2), 242-243.

https://doi.org/10.7202/1022457ar

Tous droits réservés (C Département des relations industrielles de l’Université Laval, 1958
Ce document est protégé par la loi sur le droit d'auteur. L'utilisation des services d'Érudit (y compris la reproduction) est assujettie à sa politique d'utilisation que vous pouvez consulter en ligne.

https://apropos.erudit.org/fr/usagers/politique-dutilisation/ 
Cette partie de l'enquête nous semble donc particulièrement révélatrice et nous permet de prendre connaissance, par exemple, de jugements de valeur des auteurs eux-mêmes qui ne manquent pas de nous suggérer des comparaisons avec ce qui existe chez nous, entre aıtres ceux-ci:

«Traditionally, hospitals kept their costs down by hiring workers at less than prevailing wages. »

\section{Ou encore:}

«Hospital employment acquired the stigma of charity. To accept work there came to be seen as an admission that you couldn't get work anywhere else. »

\section{Et enfin:}

«The oldtime employees continue on its payroll partly because they are so desperately needed, and partly because in many cases there are no pension plans to face their retirement... »

\section{pp. 162 et 163}

Les auteurs signalent, au tout début, que les 7,000 hôpitaux des Etats-Unis emploient 1,200.000 salariés et dépensent approximativement $\$ 4,000,000,000$ par année. Or, fait incompréhensible, ce n'est qu'à l'avenant et comme subsidiairement que l'on aborde la question des salaires. Constatation encore plus surprenante, le fait syndical est presque totalement ignoré. La seule allusion, très modeste par ailleurs, au fait syndical, on la trouve dans une dizaine de lignes à la page 16 ; et il ne s'agit pour les auteurs que de signaler que les hôpitaux, jusqu'à un certain point «must compete with union wages and fringe benefits to get and keep satisfied employees ». Pas de statistiques concernant la proportion des salariés syndiqués ou non, et il est à ma connaissance que même si les unions américaines n'ont pas pénétré le domaine hospitalier au même degré que chez nous, il existe des unions d'employés d'hôpitaux aux Etats-Unis.

Quoi qu'il en soit, la contribution des auteurs m'apparaît nettement digne d'intérêt et elle indique tout au moins qu'une semblable étude aurait certes sa valeur et son utilité chez nous.

\section{JaCQues Archambault}

Labor Relations and Productivity in the Building Trades. By W. Haber and H.M. Levinson. Ann Arbor: Bureau of Industrial Relations, University of Michigan, 1956. 266 pp. $\$ 4.75$.

Peu de travaux ont été publiés sur les problèmes d'une catégorie industrielle particulière, spécialement autant que l'industrie de la construction est conoernée. Pourtant, celle-ci est l'une des plus importantes de la nation tant comme employeur que comme producteur et constitue l'un des principaux déterminants du volume de la production nationale. Dans ce sens, la monographie de Haber et Levinson est un apport extrêmement imposant à la connaissance des relations ouvrières et de la productivité dans l'industrie de la construction.

La disparité de l'industrie, la multiplicité des unités, le caractère local des marchés, la nature de l'offre et de la demande, l'organisation syndicale, la structure et le fonctionnement de l'industrie forment un tout complexe qui conditionne les relations patronalesouvrières et la productivité. Les auteurs ont bien compris l'incidence de cet arrière-plan socio-économique. Ils l'ont décrit avec clarté et concision, sans négliger la précision. Ils ont su l'utiliser pour situer les problèmes étudiés et des faire comprendre. Ils ont su, malgré les limitations et les difficultés rencontrées, tirer des conclusions et établir des faits qui détruisent plusieurs préjugés entretenus à l'égard des employeurs ou des unions.

Après avoir dégagé les caractéristiques économiques de l'industrie, les auteurs montrent comment l'atelier fermé y est l'un des joints fondamentaux des relations patronales-ouvrières. Parmi les questions couvertes, signalons les attitudes des employeurs et des unions envers l'apprentissage, les effets des innovations techniques (matériel-outil) sur la productivité et les attitudes des unions, les tendances comparatives des salaires et de la productivité, la naturne, le degré et l'effet des réglementations des unions «working rules». Les auteurs font sur chacun de ces points d'intéressantes et constructives comparaisons entre les secteurs unionisés et non unionisés. Ils étudient aussi l'action des employeurs et des unions vis-à-vis la loi, principalement le TaftHartley Act. 
Labor Relations and Productivity in the Building Trades est une oeuvre bien faite et objective que nous recommendons sans réserve aux employeurs et aux chefs ouvriers de ce secteur industriel, ainsi qu'aux étudiants.

\section{Louis-Marie Tremblay}

Profit Sharing in American Business. By Edwin B. Flippo: Columbus, Ohio: Bureau of Business Research, College of Commerce and Administration, Ohio State University, 1954. 183 pp. $\$ 3.00$.

The reader must not expect an economic theory of wealth distribution from this discussion of Employee Profit Sharing. The book is concerned primarily with the problem of plan administration. It takes Profit Sharing plans as a fact which can be and has been observed. It is neither the purpose of the author to make a case for or against profit sharing. On the contrary, he does not take sides. $\mathrm{He}$ intends only to make a factual analysis of the methods of administering employee profit sharing plans from a survey of experience in order that they may be properly maintained during normal times and substained in periods of stress.

Profit Sharing is defined as follows: «An agreement freely entered into, by which the employees receive a share, fixed in advance, of the profits ». The author does not take account of the other forms of participation in company benefits such as production bonus systems.

Chapter two is a brief outline of the philosophy behind Profit Sharing plans. It describes without discussing them the objectives of and the objections to, establishing profit sharing, and gives the usual details of the sharing mechanism, such as: Employee Profit Sharing plans, (types of plans, company contributions, eligibility requinements, bases for distribution of shanes...). The following chapters deal with the techniques and methods of maintaining profit sharing plans on a continuous basis even during nonprofit years, with a particular emphasis upon employee education. They are a comprehensive analyses, both qualitative and quantitative, of data developed by questionnaire in a representative number of business firms in the U.S. and Canada, according to size of industries and types of sharing plans, which are: Current Distribution, Deferred Distribution and Combinations of both. An objective attempt is made to present the experience regarding attitudes of labor unions toward profit sharing. The book ends with a good analysis of the factors governing the success or failure of employee profit sharing.

This book would not be of great interest to the economist and the sociologist, but would be very useful and informative for the firms that have, or are facing profit shaning.

Louis-Marie Tremblay

Yves Martin: professeur de Sociologie, Faculté des sciences sociales de Laval; GÉRARD DION: directeur, Département des relations industrielles de Laval; C.-RAYmond Maranda: M.Sc.Soc., directeur des placements spéciaux, Service national de Placement; Rodrigue GIRoux: Ph.D. (Psych.), bureau du personnel de la Cie de Transport provinciaie; JacQues Archambault: M.Sc.Soc., conseiller technique, CTCC; Louis-Marie Tremblay: M.Sc.Soc., Centre de recherches sociales, Faculté des sciences sociales de Laval. 